\title{
Analysis of epidermal growth factor receptor and activated epidermal growth factor receptor expression in pituitary adenomas and carcinomas
}

\author{
Onder Onguru ${ }^{1,2}$, Bernd W Scheithauer ${ }^{1}$, Kalman Kovacs ${ }^{1,3}$, Sergio Vidal ${ }^{1,3}$, Long Jin ${ }^{1}$, \\ Shuya Zhang ${ }^{1}$, Katharina H Ruebel ${ }^{1}$ and Ricardo V Lloyd ${ }^{1}$ \\ ${ }^{1}$ Department of Laboratory Medicine and Pathology, Mayo Clinic, Rochester, Minnesota, MN, USA; \\ ${ }^{2}$ Department of Pathology, Gulhane Military Medical Academy, Ankara, Turkey and ${ }^{3}$ Department of \\ Laboratory Medicine and Pathology, Mayo Clinic, St Michaels Hospital, University of Toronto, Toronto, \\ Canada
}

\begin{abstract}
Epidermal growth factor receptor plays an important role in the pathogenesis of many malignancies. Various growth factors, including epidermal growth factor receptor, have been shown to influence pituitary tumor growth and differentiation. To analyze the role of epidermal growth factor receptor in pituitary tumor development, we examined normal pituitaries $(n=8)$, pituitary adenomas $(n=158)$, and pituitary carcinomas $(n=7)$ for expression of epidermal growth factor receptor protein and messenger RNA using tissue microarrays and RT-PCR. We also examined (a) the expression of phospho-epidermal growth factor receptor, the activated form of epidermal growth factor receptor, in pituitary tumors and normal pituitaries by immunohistochemistry and (b) the effects on epidermal growth factor receptor expression of treating pituitary cells (HP75 cell line) with epidermal growth factor. Epidermal growth factor receptor and the phosphorylated variant expression were present in normal pituitary cells. Epidermal growth factor receptor messenger RNA was also detected in normal pituitaries, pituitary adenomas, and carcinomas by in situ hybridization and RT-PCR. Most pituitary adenomas showed expression of epidermal growth factor receptor and the phosphorylated variant. Nonfunctional adenomas showed higher levels of expression of epidermal growth factor receptor (76 vs $34 \%$ ) and of phosphoepidermal growth factor receptor (26 vs $8 \%$ ) as compared to functional adenomas. Five of seven pituitary carcinomas showed strong expression of both epidermal growth factor receptor and phospho-epidermal growth factor receptor. When a human pituitary cell line (HP75) was cultured in the presence of epidermal growth factor receptor, there was an increase in the levels of both epidermal growth factor receptor and phospho-epidermal growth factor receptor after $5 \mathrm{~h}$ of treatment, thus confirming that epidermal growth factor receptor signaling was active in pituitary tumors. These results indicate that activated epidermal growth factor receptor is expressed in pituitary adenomas and carcinomas. Higher levels in pituitary carcinomas suggest a role in pituitary tumor progression.
\end{abstract}

Modern Pathology (2004) 17, 772-780, advance online publication, 16 April 2004; doi:10.1038/modpathol.3800118

Keywords: epidermal growth factor receptor; phosphorylated epidermal growth factor receptor; pituitary adenoma; pituitary carcinoma; immunohistochemistry; RT-PCR

Growth factors and growth factor receptors play an important role in the pathogenesis of many human malignancies. Epidermal growth factor receptor (EGFR) belongs to the family of receptor tyrosine kinases, of which there are 20 functionally related

Correspondence: Dr RV Lloyd, MD, PhD, Department of Laboratory Medicine and Pathology, Mayo Clinic, 200 1st Street SW, Rochester, MN 55905, USA.

E-mail: lloyd.ricardo@mayo.edu

Received 1 December 2003; revised 10 February 2004; accepted 16 February 2004; published online 16 April 2004 but structurally distinct forms. The epidermal growth factor receptor subfamily consists of four closely related receptors: EGFR (HER1 or ErbB1), HER2 (or ErbB2/neu), HER3 (or ErbB3), and HER4 (ErbB4). ${ }^{1}$ Structurally, each is a transmembrane glycoprotein composed of an amino-terminal extracellular domain, a hydrophobic transmembrane region, and a cytoplasmic domain that contains both the tyrosine kinase domain and a carboxyterminal region with intrinsic tyrosine kinase activity.,3 Binding of specific ligands, such as epidermal growth factor (EGF) and transforming 
growth factor- $\alpha$, to EGFR results in dimerization of the receptor and autophosphorylation of its intracellular domain., ${ }^{4,5}$ There are at least two pathways (ras-raf-1-MAPK and PI3K-Akt) involved in downstream EGFR signaling. Phosphorylation of MAPK causes activation of several transcription factors for example, Elk-1, Sap-1, c-Myc, etc. In contrast, activation of Akt inhibits the apoptosis-inducing proteins Bcl-2 and caspase-9. Activation of these pathways leads to mitogenic signaling responsible for a number of processes crucial to tumor progression by way of proliferation, decreased apoptosis, angiogenesis, and invasion. ${ }^{4}$

EGFR is expressed by many cell types, especially glandular epithelial cells. ${ }^{6}$ EGFR expression is elevated in many epithelial tumors and tumorderived cell lines. Coexpression of high levels of EGFR and its ligands leads to a transformed cellular phenotype. ${ }^{7}$ In the majority of tumors, overexpression may not be associated with detectable alterations of the EGFR gene. Exceptions to this observation include gliomas and squamous cell carcinomas, which show amplification of EGFR. ${ }^{8}$ While in some studies EGFR expression has been correlated with markers of clinical aggression, ${ }^{9-11}$ a recent meta-analysis indicated that EGFR expression was rarely related to clinical outcome. ${ }^{12}$ Yet another study suggested that phosphorylation of EGFR, but not its overexpression, might be associated with a poor prognosis. ${ }^{13}$

Polypeptide growth factors activate growthpromoting pathways to induce cell proliferation. They have been implicated in the multistep pathway of tumorigenesis ${ }^{14-16}$ and may play a role in pituitary neoplasia. ${ }^{17}$ Ligand binding with resultant EGFR activation is thought to be the most important step in the signal transduction pathway. EGFR expression and its specific ligands have been examined in pituitary adenomas with variable results. ${ }^{18}$ PhosphoEGFR (P-EGFR), the activated form of EGFR in pituitary adenomas and carcinomas, has not been previously examined. In this study, we investigated the expression and activation state of EGFR in normal pituitaries, pituitary adenomas, and carcinomas by immunohistochemistry and in situ hybridization using tissue microarrays (TMAs). RT-PCR was used to analyze EGFR mRNA expression.

\section{Materials and methods}

\section{Tissues}

Normal pituitaries $(n=8)$ were obtained within $6 \mathrm{~h}$ after death and fixed in buffered formalin. Pituitary adenomas including 17 adrenocorticotropic hormone (ACTH) adenomas, 23 growth hormone (GH) adenomas, and 22 prolactin (PRL) adenomas, 43 gonadotroph (LH/FSH) adenomas, and 53 null cell adenomas were obtained from Mayo Clinic files. All adenomas had been previously characterized by immunostaining with pituitary antibodies. Patients with GH adenomas all had acromegaly at presentation. Seven immunohistochemically characterized pituitary carcinomas (three ACTH, three PRL, and one LH/FSH) previously characterized by immunostaining were obtained both from the files of the Mayo Clinic and the consultation files of one of the authors (BWS). By definition, carcinomas were associated with metastatic disease.

Tissue microarrays consisting of three $(0.6 \mathrm{~mm})$ cores of each specimen with interspersed normal liver tissues were made according to the previously described method. ${ }^{19,20}$ For the purpose of immunohistochemical and in situ hybridization (ISH) analyses, sections were cut at $5 \mu \mathrm{m}$ onto positively charged slides and used.

\section{Immunohistochemistry}

Antibodies for the full spectrum of pituitary hormones (GH, PRL, ACTH, LH, FSH, TSH) were obtained from the National Pituitary Agency and used as previously described. ${ }^{21}$.Polyclonal rabbit antibodies to C-terminus epitope of EGFR were obtained from Santa Cruz Biotechnology, Santa Cruz, CA, USA (cat \#1005; dilution 1:250) and mouse monoclonal antibody to P-EGFR (Tyr1068) from Cell Signaling Technology, Beverly, MA, USA (cat \#2236S; dilution 1:100).

Tissue sections were microwave heated for $5 \mathrm{~min}$ in an $800-W$ oven while in citrate buffer $(0.1 \mathrm{mM}, \mathrm{pH}$ 6.0). Sections were then incubated at room temperature overnight with primary antibody. Immunostaining was performed with the avidin-biotin complex (ABC) method (Vector, Burlingame, CA, USA). Negative controls consisted of substituting normal serum for primary antibodies.

\section{ISH}

The human EGFR cDNA, cloned into pBSFLu plasmid and linearized with EcoRI or PstI were a gift from Dr NJ Maihle. ${ }^{22}$ The reverse transcription reaction and digoxigenin 11-UTP (Boehringer Mannheim, Indianapolis, IN, USA) labeling were performed with T7 (antisense) and T3 (sense) RNA polymerase, provided in the riboprobe labeling kit following the manufacturer's instruction (Promega, Madison, WI, USA). The labeled probes were digested with deoxyribonuclease, extracted with phenol/chloroform, and precipitated with ethanol.

The ISH procedure was performed on the tissue microarray as previously described. ${ }^{23,24}$ Positive ISH signals were detected using the anti-digoxigenin AP (1:200; Boehringer Mannheim) NBT/BCIP system.

\section{Cell Culture}

HP75 pituitary cells were cultured in Dulbecco's modified essential medium (DMEM) with $2 \%$ fetal 
bovine serum as previously reported. ${ }^{25}$ Cells were treated with $1 \mu \mathrm{g} / \mathrm{ml}$ EGF (Promega, Madison, WI, USA) for 5 and $24 \mathrm{~h}$ and were then harvested. Proteins were extracted and used for Western blotting as described below.

\section{Western Blotting}

Western blotting was performed as previously described. ${ }^{26}$ Briefly, proteins were extracted in the presence of protease inhibitors. One-dimensional sodium dodecyl sulfate polyacrylamide gel electrophoresis was then performed on a $12 \%$ gel. The electrophoresed protein $(50 \mu \mathrm{g})$ was transformed to a polyvinylidene difluoride membrane (Bio-Rad, Richmond, CA, USA) and subjected to immunoblot analysis with antibodies directed against EGFR (1:200) and P-EGFR (1:1000). The reaction product was detected by enhanced chemiluminescence (Amersham, Arlington Heights, IL, USA).

\section{RT-PCR}

Total RNA extraction was performed using the TRIzol reagent kit (Life Technologies) on two normal pituitaries, nine adenomas (two PRL, two GH, two LH/FSH, one ACTH, and two null cell) as well as one ACTH carcinoma. First-strand complementary DNA (cDNA) was prepared from total RNA by using a first-strand RT-PCR kit (Stratagene, La Jolla, CA, USA). The RT reaction was performed at $42^{\circ} \mathrm{C}$ for $60 \mathrm{~min}$ in a final volume of $50 \mu \mathrm{l}$ containing $1 \mu \mathrm{g}$ of total RNA. The reaction product was then heated at $95^{\circ} \mathrm{C}$ for $5 \mathrm{~min}$ and immediately placed on ice.

The oligonucleotide primers for EGFR were as follows: sense, 5' ${ }^{\prime}$-TCT CAG CAA CAT GTC GAT GG-3'; antisense, 5' ${ }^{\prime}$-TCG CAC TTC TTA CAC TTG CG-3'. Spanning four introns between exons 8 and 12 of the human EGFR genomic DNA (\#X00588), these primers generate a 473-bp product (702-1175). The integrity of the RNA from each sample was verified by RT-PCR for hypoxanthine phosphoribosyl transferase (HPRT). The primers used to identify HPRT (\#M31642) were as follows: sense, $5^{\prime}$ - CTT GCT CGA GAT GTG ATG AGG-3'; antisense, $5^{\prime}$ - GTC TGC ATT GTT TTG CCA GTG $-3^{\prime}$. These primers span three introns between exons 3 and 6 and generate a 290-bp product (230-519). The PCR was performed in $25 \mu \mathrm{l}$ final reaction volumes containing the following: $2.5 \mu \mathrm{l}$ of RT reaction product as template DNA, $1 \times$ PCR buffer (Promega, Madison, WI, USA), $2 \mathrm{mmol} / \mathrm{l}$ $\mathrm{MgCl}_{2}, 0.2 \mathrm{mmol} / \mathrm{l}$ of each deoxynucleotide (Roche Molecular Biochemicals, Indianapolis, IN, USA), $0.2 \mu \mathrm{M}$ of sense and antisense primers for EGFR, and 1.25 U Taq DNA polymerase (Promega). Progamable temperature cycling (GeneAmp PCR System 9700, Applied Biosystems) was performed with the following cycle profile: $95^{\circ} \mathrm{C}$ for $5 \mathrm{~min}$, followed by $94^{\circ} \mathrm{C}$ for $30 \mathrm{~s}, 61^{\circ} \mathrm{C}$ for $30 \mathrm{~s}$, and $72^{\circ} \mathrm{C}$ for $45 \mathrm{~s}(35$ cycles) for EGFR and $94^{\circ} \mathrm{C}$ for $30 \mathrm{~s}, 58^{\circ} \mathrm{C}$ for $30 \mathrm{~s}$, and $72^{\circ} \mathrm{C}$ for $30 \mathrm{~s}$ (30 cycles) for HPRT. After the last cycle the elongation step was extended at $72^{\circ} \mathrm{C}$ for $10 \mathrm{~min}$. A $20 \mu \mathrm{l}$ aliquot of PCR product was analyzed by gel electrophoresis using a $2 \%$ agarose gel and was stained with ethidium bromide. A $100 \mathrm{bp}$ ladder (Roche) was used as the standard.

\section{Evaluation and Statistical Analysis}

Two observers evaluated the microarray sections. Immunoreactivity was graded using a three-point scale: negative $(-)$; weakly positive $(1+)$, less than $10 \%$ of the cells being stained or weakly stained; moderately to strongly positive $(2+-3+)$, over $10 \%$ of the tumor cells being strongly stained.

The two-sided Fisher's exact test and the $\chi^{2}$-test, both at the $95 \%$ confidence level, were used to check for an association between staining intensity and the functional status of adenomas. SPSS for Windows 9.0 (SPSS Inc., Chicago, IL, USA) software was used for analyses.

\section{Results}

\section{Immunohistochemistry}

EGFR

Variable immunoreactivity was present in pituitary adenomas, pituitary carcinomas, and in normal pituitary tissues (Table 1). The staining pattern was usually diffuse (Figure 1). EGFR expression in normal pituitaries was weak in six cases $(75 \%)$ and strong in two (25\%). Expression in pituitary adenomas was strong in 94 (59\%) and weak in 61

Table 1 Distribution of EGFR immunoreactivity in normal and neoplastic pituitaries

\begin{tabular}{lccrr}
\hline Diagnosis & $\mathrm{n}$ & Negative & Weakly positive (1+) & Moderately to strongly positive (2-3+) \\
\hline Normal pituitary & 8 & 0 & $6(75 \%)$ & $2(25 \%)$ \\
ACTH adenoma & 17 & $1(6 \%)$ & $13(76 \%)$ & $3(18 \%)$ \\
Growth hormone adenoma & 23 & $1(4 \%)$ & $14(61 \%)$ & $8(35 \%)$ \\
Prolactin adenoma & 22 & $1(5 \%)$ & $11(50 \%)$ & $10(45 \%)$ \\
LH/FSH adenoma & 43 & 0 & $11(26 \%)$ & $32(74 \%)$ \\
Null cell adenoma & 53 & 0 & $12(23 \%)$ & $41(77 \%)$ \\
Carcinoma & 7 & $1(14 \%)$ & $1(14 \%)$ & $5(72 \%)$ \\
\hline
\end{tabular}



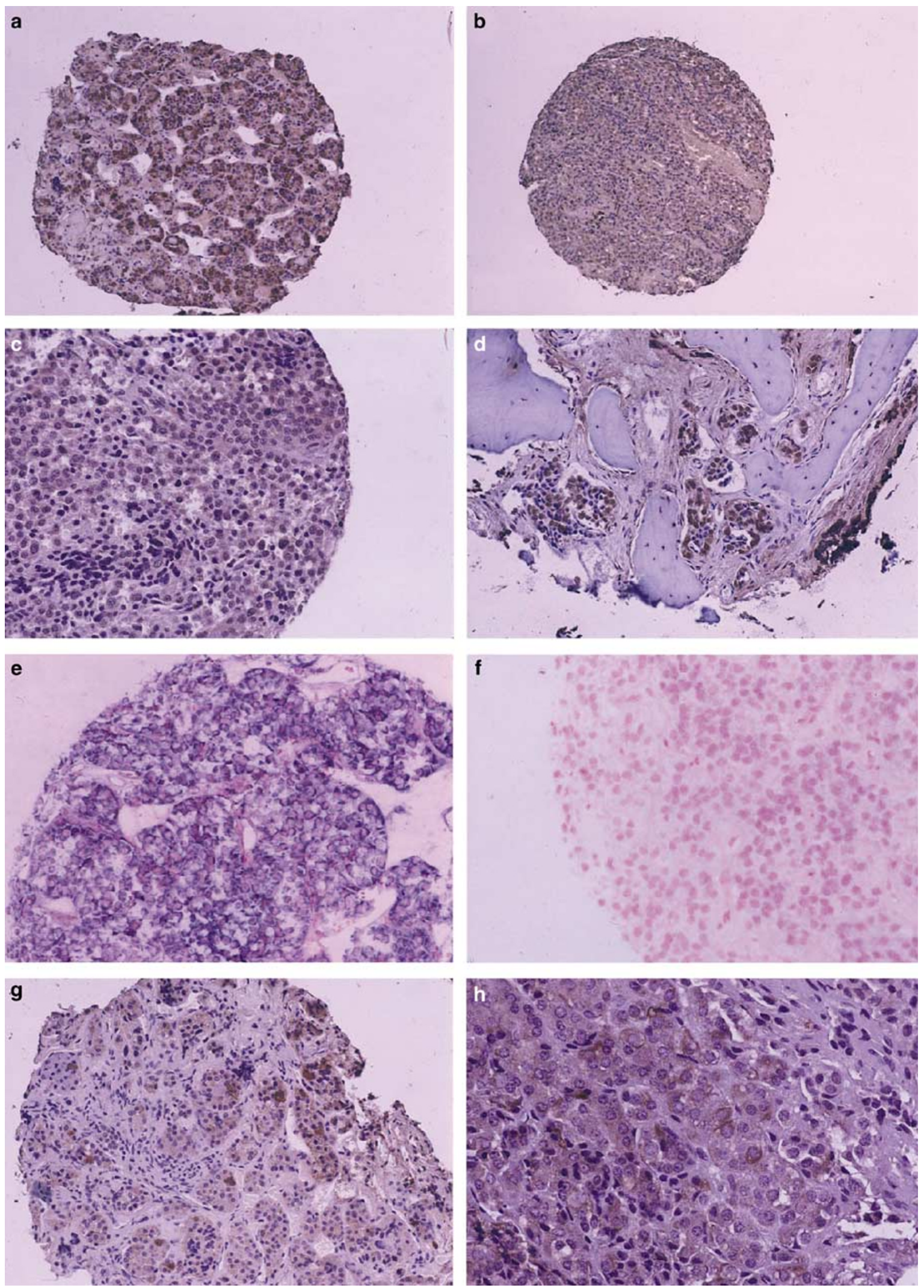

Figure 1 (a) EGFR immunoreactivity in normal anterior pituitary shows variable staining. (b) LH/FSH adenoma shows strong staining for EGFR. (c) ACTH adenoma shows weak staining for EGFR. (d) Pituitary carcinoma metastatic to bone showing strong staining for EGFR. (e) ISH antisense probe detecting strong reactivity for EGFR mRNA in an LH/FSH adenoma. (f) Control sense probe shows no staining for EGFR in an LH/FSH adenoma. (g) P-EGFR immunoreactivity in normal anterior pituitary cells. A few cells show strong immunoreactivity. (h) Null cell adenoma showing strong staining for activated P-EGFR in some tumor cells. 


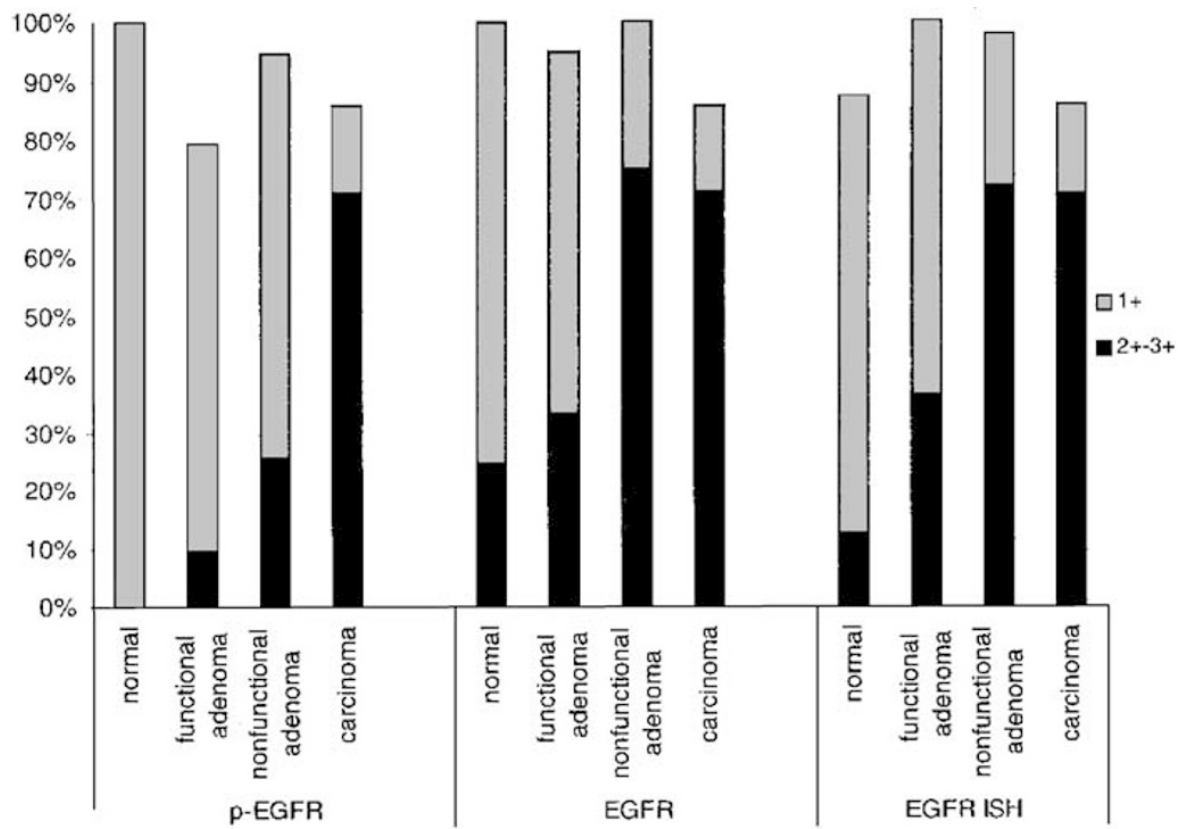

Figure 2 P-EGFR and epidermal growth factor receptor (EGFR) immunoexpression and ISH results for EGFR in pituitary tumors (functional adenomas $n=62$, nonfunctional adenomas $n=96$, pituitary carcinomas $n=7$ ) and normal pituitaries $(n=8)$ (weak positivity $1+$, strong positivity $2+-3+$ ).

Table 2 Distribution of P-EGFR immunoreactivity in normal and neoplastic pituitaries

\begin{tabular}{lcccc}
\hline Diagnosis & $\mathrm{n}$ & Negative & Weakly positive (1+) & Moderately to strongly positive(2-3+) \\
\hline Normal pituitary & 8 & 0 & $8(100 \%)$ & 0 \\
ACTH adenoma & 17 & $3(18 \%)$ & $13(76 \%)$ & $1(6 \%)$ \\
Growth hormone adenoma & 23 & $8(35 \%)$ & $14(61 \%)$ & $1(4 \%)$ \\
Prolactin adenoma & 22 & $2(9 \%)$ & $17(77 \%)$ & $3(14 \%)$ \\
LH/FSH adenoma (GTH) & 43 & $5(12 \%)$ & $27(63 \%)$ & $11(25 \%)$ \\
Null cell adenoma & 53 & 0 & $39(74 \%)$ & $14(26 \%)$ \\
Carcinoma & 7 & $1(14 \%)$ & $1(14 \%)$ & $5(72 \%)$ \\
\hline
\end{tabular}

(39\%). Of the seven pituitary carcinomas, five (2 ACTH, 2 PRL, 1 LH/FSH) showed strong EGFR expression, one ACTH carcinoma showed weak expression, and one PRL carcinoma was immunonegative. Functional pituitary tumors (PRL, GH and ACTH) usually stained less intensely than nonfunctional (LH/FSH and null cell) tumors (Figure 2). The difference in staining intensity between functional and nonfunctional adenomas was statistically significant $(P<0.001)$.

\section{$P$-EGFR}

In pituitary adenomas, the number of cases and percentage of cells positively staining for P-EGFR was generally lower than for EGFR (Table 2, Figures 1 and 2). In normal pituitaries, the expression of $\mathrm{P}$ EGFR was weak in all samples. Strong immunoreactivity was observed in single scattered cells of the normal pituitary. The expression of P-EGFR was highest in null cell adenomas (strong in $26 \%$, weak in $74 \%$ ) and in LH/FSH adenomas (strong in $25 \%$, weak in $63 \%$, negative in $12 \%$ ). Staining was generally weaker in functional adenomas. The staining intensity between functional and nonfunctional adenomas was statistically significant $(P=0.001)$. The expression of P-EGFR in pituitary carcinomas was strong in five $(72 \%)$, weak in one $(14 \%)$, and negative in one $(14 \%)$.

\section{ISH for EGFR}

ISH using EGFR riboprobes on tissue microarrays generally showed weak positivity in normal pituitary tissue (strong positivity in one, weak positivity in six, and no signal in one case) (Table 3, Figures 1 and 2). In all, 41 (77\%) of null cell adenomas and 29 $(68 \%)$ of LH/FSH adenomas were moderately to strongly positive. Among the functional adenomas, 12 PRL adenomas (55\%), eight GH adenomas (35\%) and three ACTH adenomas (18\%) showed strong positivity. The staining intensity between functional 
Table 3 ISH analysis of EGFR mRNA in normal and neoplastic pituitaries

\begin{tabular}{|c|c|c|c|c|}
\hline Diagnosis & $\mathrm{n}$ & Negative & Weakly positive $(1+)$ & Moderately to strongly positive (2-3+) \\
\hline Normal pituitary & 8 & $1(13 \%)$ & $6(74 \%)$ & $1(13 \%)$ \\
\hline ACTH adenoma & 17 & 0 & $14(82 \%)$ & $3(18 \%)$ \\
\hline Growth hormone adenoma & 23 & 0 & $15(65 \%)$ & $8(35 \%)$ \\
\hline Prolactin adenoma & 22 & 0 & $10(45 \%)$ & $12(55 \%)$ \\
\hline LH/FSH adenoma (GTH) & 43 & $1(2 \%)$ & $13(30 \%)$ & $29(68 \%)$ \\
\hline Null cell adenoma & 53 & $1(2 \%)$ & $11(21 \%)$ & $41(77 \%)$ \\
\hline Carcinoma & 7 & $1(14 \%)$ & $1(14 \%)$ & $5(72 \%)$ \\
\hline
\end{tabular}

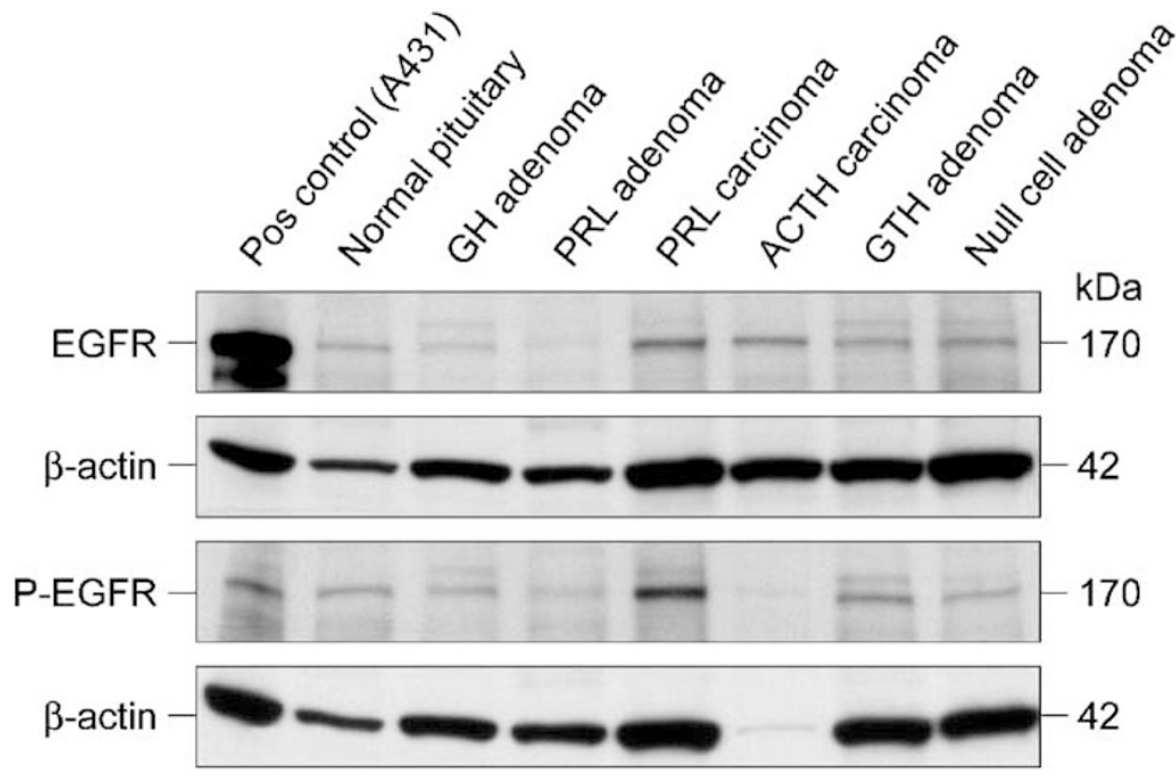

Figure 3 Western blot analysis of EGFR and P-EGFR in normal and neoplastic pituitaries. The nonfunctional adenomas and carcinomas had higher levels of EGFR and P-EGFR expression compared to normal pituitaries and functional (GH, PRL) adenomas. Beta actin was used to check for equal loading of the gel.

and nonfunctional adenomas was statistically significant $(P<0.001)$. Five pituitary carcinomas showed strong positivity.

\section{Western Blots}

Western blot analysis of the normal pituitary showed a 170-kDa band for EGFR. LH/FSH and null cell adenomas showed similar bands with a stronger expression than seen in the PRL adenoma or normal pituitary tissue. The expression of EGFR was strong in both ACTH and the PRL carcinomas (Figure 3).

Western blot analysis for P-EGFR showed a 170$\mathrm{kDa}$ band that was more strongly expressed in adenomas and carcinomas compared to the normal pituitary.

\section{Cell Culture}

After $5 \mathrm{~h}$ of treatment with EGF, there was a two-fold increase in the levels of P-EGFR. After $24 \mathrm{~h}$ of culture, both levels decreased and returned almost to control levels (Figure 4).

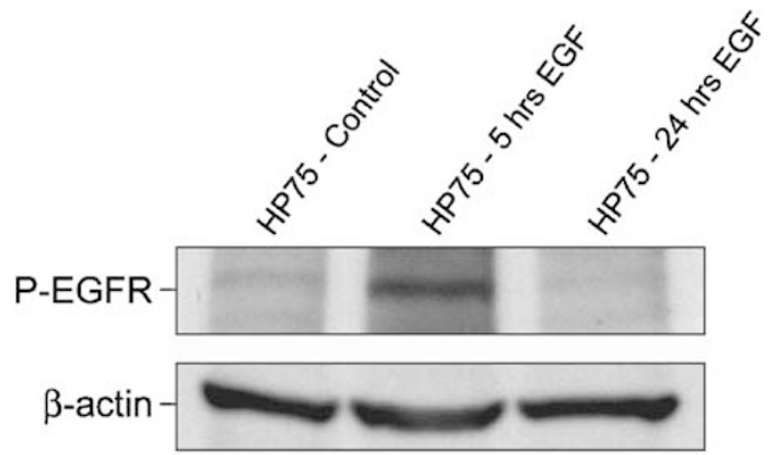

Figure 4 Western blot analysis of the effects of EGF treatment on P-EGFR expression in cultured HP75 cells. Cells were cultured for 5 and $24 \mathrm{~h}$ in the presence of EGF and then harvested and analyzed by Western blot.

\section{RT-PCR}

EGFR mRNA expression was detected in all samples analyzed, which included two normal pituitaries, nine adenomas (two PRL, two GH, one ACTH, two 
LH/FSH (GTH), and two null cell), as well as one carcinoma producing ACTH (Figure 5).

\section{Discussion}

In the present study, we examined the expression of EGFR in pituitary tissue and its neoplasms by both immunohistochemistry and ISH using tissue microarrays. Assessment of pituitary adenomas showed EGFR expression in the majority by both methods. Overall, about $60 \%$ of the adenomas were moderately to strongly positive for EGFR. Although its overexpression was highly variable within each subgroup, expression was higher (76 vs 34\%) in the nonfunctional (LH/FSH and null cell adenomas) compared to the functional adenomas (ACTH, PRL, GH). Among the latter, ACTH adenomas showed the lowest percentage of tumors expressing EGFR. The finding of stronger EGFR expression in nonfunctional tumors in our study is similar to the result obtained by LeRiche et $a l^{27}$ and Chaidarun et $a l^{28}$

Expression of EGFR does not necessarily indicate receptor activation. Our analysis of pituitary adenomas using tissue microarrays showed variable expression of both EGFR and P-EGFR, the activated form of EGFR, in various subgroups of pituitary adenomas. The expression of P-EGFR was consistently less than that of EGFR. It is well established that ligand-induced autophosphorylation of EGFR involves receptor dimerization. ${ }^{29}$ Ligand-driven receptor activation, rather than overexpression, is said to be crucial to proliferation in an androgenindependent prostate cancer cell line. ${ }^{30}$ The concomitant expression of EGFR and its ligands is described as a mechanism of cancer cell autocrine stimulation resulting in clinically aggressive disease. $^{7}$
The detection of increased levels of EGFR and P-EGFR after $5 \mathrm{~h}$ of EGF stimulation of cultured human pituitary cells supports our observation of activation of EGFR in pituitary tumors after ligand interaction.

In an earlier study of EGF-binding sites in pituitary adenomas using membrane-binding assays, Birman et $a l^{31}$ reported that EGF-binding sites were present in normal human pituitary, but not in either functional or nonfunctional pituitary adenomas. However, subsequent studies using either immunohistochemistry or RT-PCR reported the presence of EGFR in pituitary adenomas with varying results. ${ }^{27,28,32,33}$ Variation may also result from tumor heterogeneity and variations in tumor classification. EGF-binding sites with highly variable expression were also found by competitive binding assays in a study of 46 pituitary macroadenomas. EGFR positivity was observed in $55 \%$, especially in prolactinomas $(76 \%)$ and in LH/FSH adenomas $(62 \%) .{ }^{34}$ In their study, two classes of EGF binding sites were shown with respective high and low affinities. The latter could reflect the capacity of EGFR to present allosteric modifications, especially dimerization, following ligand binding.

Our study is the first to show the expression of EGFR in pituitary carcinomas. Five of the seven tumors studied (two ACTH, two PRL, and one LH/ FSH pituitary carcinoma) showed strong immunoreactivity for EGFR and P-EGFR. In only one case report, an immunohistochemical study of a single PRL cell carcinoma, no EGFR was detected. ${ }^{35}$ Comparison of pituitary adenomas and carcinomas in our study showed that carcinomas were more likely to overexpress EGFR and P-EGFR as compared to adenomas. This finding was especially noticeable with comparing functional adenomas, especially ACTH and GH adenomas, and carcinomas

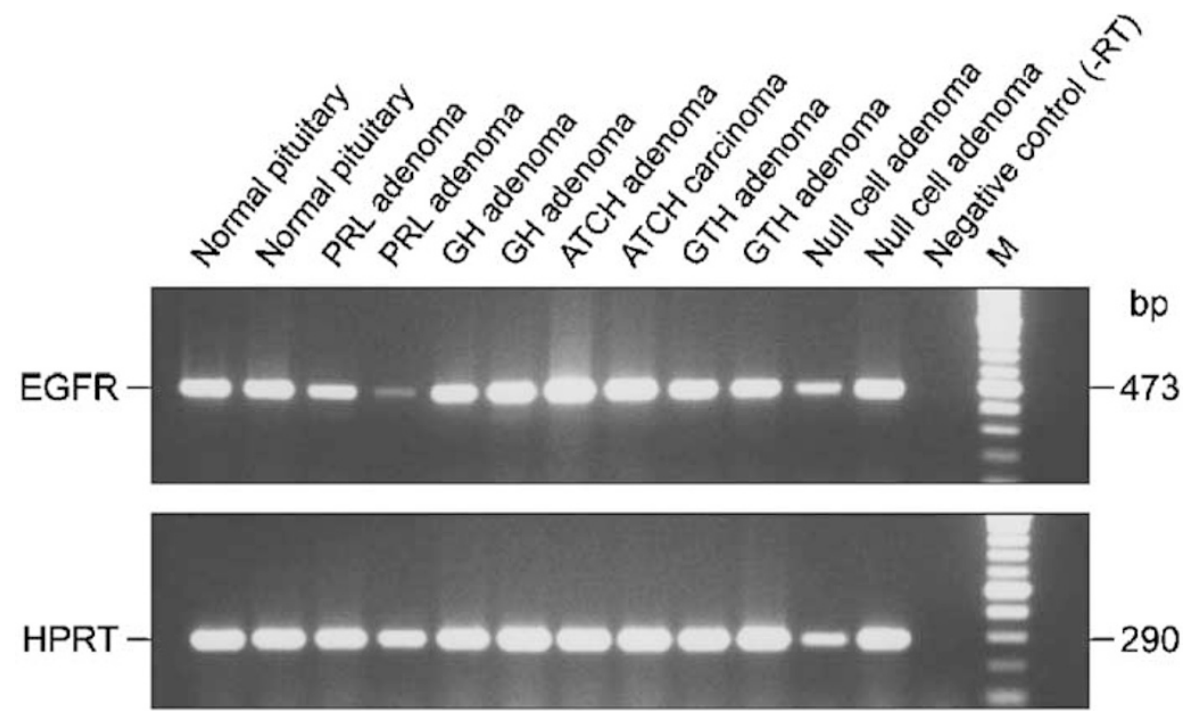

Figure 5 RT-PCR analysis of EGFR in normal pituitaries, pituitary adenomas, and pituitary carcinomas. The 473 bp transcript was detected in all samples. HPRT was used to check for equal loading of the gel. 
for P-EGFR expression. Collectively, these findings suggest a role of EGFR in pituitary tumor progression.

Several studies have examined EGFR production by normal anterior pituitary cells. ${ }^{27,31}$ Expression of EGFR was present at a low level in $5-10 \%$ of pituitary cells in one study. ${ }^{28}$ In our study of normal pituitary, expression of EGFR, P-EGFR protein, and EGFR mRNA was detected. Expression of EGFR and P-EGFR varied in different cell types within the anterior pituitary lobules. One study of the rat adenohypophysis showed that EGFR is present in subsets of all pituitary cell types. ${ }^{36}$ In another study, the expression of EGFR in gonadotropes of female rats varied with the stage of the ovulatory cycle, probably due to the stimulation of gonadotropinreleasing hormone and the paracrine/autocrine effect of EGF. ${ }^{37}$

It has been suggested that high EGFR expression may be a late event in pituitary tumorigenesis (34) and a marker of aggressiveness in a significant subset of pituitary tumors. ${ }^{27,34}$ The mechanisms by which the EGF family of growth factors promotes proliferation and invasiveness of pituitary adenoma cells will require additional studies.

In summary, normal and neoplastic pituitary tissues express EGFR and P-EGFR, levels of EGFR being higher in pituitary carcinomas as compared to normal pituitaries and adenomas. Nonfunctional adenomas express higher levels of EGFR and P-EGFR than do functional adenomas. Stimulation of cultured human pituitary cells with EGF leads to increased levels of EGFR and P-EGFR, indicating that this receptor tyrosine kinase pathway is important in pituitary tumor progression.

\section{Acknowledgements}

This work was supported in part by NIH Grant (NCI CA 90249). During this study, Dr Onder Onguru was supported by the Turkish Armed Forces. We thank Drs NJ Maihle and JL Reiter for the EGFR probe.

\section{References}

1 Hackel PO, Zwick E, Prenzel N, et al. Epidermal growth factor receptors: critical mediators of multiple receptor pathways. Curr Opin Cell Biol 1999;11: 184-189.

2 Schlessinger J. Cell signaling by receptor tyrosine kinases. Cell 2000;103:211-225.

3 Riese DJ, Stern DF. Specificity within the EGF family/ ErbB receptor family signaling network. Bioessays 1998;20:41-48.

4 Raben D, Helfrich BA, Chan D, et al. ZD1839, a selective epidermal growth factor receptor tyrosine kinase inhibitor, alone and in combination with radiation and chemotherapy as a new therapeutic strategy in non-small cell lung cancer. Semin Oncol 2002;29(Suppl 4):37-46.
5 Cohen S. The epidermal growth factor (EGF). Cancer 1983;51:1787-1791.

6 Fukuyama R, Shimizu N. Expression of epidermal growth factor (EGF) and the EGF receptor in human tissues. J Exp Zool 1991;258:336-343.

7 Salomon DS, Brandt R, Ciardiello F, et al. Epidermal growth factor-related peptides and their receptors in human malignancies. Crit Rev Oncol Hematol 1995;19:183-232.

8 Libermann TA, Nusbaum HR, Razon N, et al. Amplification, enhanced expression and possible rearrangement of EGF receptor gene in primary human brain tumors of glial origin. Nature 1985;313:144-147.

9 Sainsbury JR, Farndon JR, Needham GK, et al. Epidermal growth-factor receptor status as predictor of early recurrence of and death from breast cancer. Lancet 1987;1:1398-1402.

10 Libermann TA, Razon N, Bartal AD, et al. Expression of epidermal growth factor receptors in human brain tumors. Cancer Res 1984;44:753-760.

11 Ozawa S, Ueda M, Ando N, et al. Prognostic significance of epidermal growth factor receptor in esophageal squamous cell carcinomas. Cancer 1989;63:2169-2173.

12 Nicholson RI, Gee JM, Harper ME. EGFR and cancer prognosis. Eur J Cancer 2001;37:S9-S15.

13 Kanematsu T, Yano S, Uehara H, et al. Phosphorylation, but not overexpression, of epidermal growth factor receptor is associated with poor prognosis of non-small cell lung cancer patients. Oncol Res 2003;13:289-298.

14 Heldin CH, Westermark B. Growth factors as transforming proteins. Eur J Biochem 1989;184:487-496.

15 Cross M, Dexter TM. Growth factors in development, transformation, and tumorigenesis. Cell 1991;64: 271-280.

16 Lang RA, Burgess AW. Autocrine growth factors and tumourigenic transformation. Immunol Today 1990;11:244-249.

17 Ezzat S, Melmed S. The role of growth factors in the pituitary. J Endocrinol Invest 1990;13:691-698.

18 Asa SL, Ezzat S. The cytogenesis and pathogenesis of pituitary adenomas. Endocr Rev 1998;19:798-827.

19 Kononen J, Bubendorf L, Kallioniemi A, et al. Tissue microarrays for high-throughput molecular profiling of tumor specimens. Nat Med 1998;4:844-847.

20 Jin L, Zhang S, Bayliss J, et al. Chromogranin a processing in human pituitary adenomas and carcinomas: analysis with region-specific antibodies. Endocr Pathol 2003;14:37-48.

21 Riss D, Jin L, Qian X, et al. Differential expression of galectin-3 in pituitary tumors. Cancer Res 2003; 63:2251-2255.

22 Reiter JL, Threadgill DW, Eley GD, et al. Comparative genomic sequence analysis and isolation of human and mouse alternative EGFR transcripts encoding truncated receptor isoforms. Genomics 2001;71 $1-20$.

23 Qian X, Jin L, Lloyd RV. Expression and regulation of transforming growth factor B1 in cultured normal and neoplastic rat pituitary cells. Endocr Pathol 1996;7: 77-90.

24 Panoskaltsis-Mortari A, Bucy RP. In situ hybridization with digoxigenin-labeled RNA probes: facts and artifacts. Biotechniques 1995;18:300-307.

25 Jin L, Kulig E, Qian X, et al. A human pituitary adenoma cell line proliferates and maintains some 
differentiated functions following expression of SV40 large T-antigen. Endocr Pathol 1998;9:169-184.

26 Lloyd RV, Jin L, Qian X, Kulig E. Aberrant p27kip1 expression in endocrine and other tumors. Am J Pathol 1997;150:401-407.

27 LeRiche VK, Asa SL, Ezzat S. Epidermal growth factor and its receptor (EGF-R) in human pituitary adenomas: EGF-R correlates with tumor aggressiveness. J Clin Endocrinol Metab 1996;81:656-662.

28 Chaidarun SS, Eggo MC, Sheppard MC, et al. Expression of epidermal growth factor (EGF), its receptor, and related oncoprotein (erbB-2) in human pituitary tumors and response to EGF in vitro. Endocrinology 1994;135:2012-2021.

29 Koch CA, Anderson D, Moran MF, et al. SH2 and SH3 domains: elements that control interactions of cytoplasmic signaling proteins. Science 1991;252:668-674.

30 Mendoza N, Phillips GL, Silva J, et al. Inhibition of ligand-mediated HER2 activation in androgen-independent prostate cancer. Cancer Res 2002;62:5485-5488.

31 Birman P, Michard M, Li JY, et al. Epidermal growth factor-binding sites, present in normal human and rat pituitaries, are absent in human pituitary adenomas. J Clin Endocrinol Metab 1987;65:275-281.

32 Kontogeorgos G, Stefaneanu L, Kovacs K, et al. Localization of Epidermal Growth Factor (EGF) and
Epidermal Growth Factor Receptor (EGFr) in human pituitary adenomas and nontumorous pituitaries: an immunocytochemical study. Endocr Pathol 1996;7: 63-70.

33 Bloomer CW, Kenyon L, Hammond E, et al. Cyclooxygenase-2 (COX-2) and Epidermal Growth Factor Receptor (EGFR) expression in human pituitary macroadenomas. Am J Clin Oncol 2003;26(Suppl 2): S75-S80.

34 Jaffrain-Rea ML, Petrangeli E, Lubrano C, et al. Epidermal growth factor binding sites in human pituitary macroadenomas. J Endocrinol 1998;158: 425-433.

35 Harada K, Arita K, Kurisu K, et al. Telomerase activity and the expression of telomerase components in pituitary adenoma with malignant transformation. Surg Neurol 2000;53:267-274.

36 Fan X, Childs GV. Epidermal growth factor and transforming growth factor-alpha messenger ribonucleic acids and their receptors in the rat anterior pituitary: localization and regulation. Endocrinology 1995;136:2284-2293.

37 Childs GV, Armstrong J. Sites of epidermal growth factor synthesis and action in the pituitary: paracrine and autocrine interactions. Clin Exp Pharmacol Physiol 2001;28:249-252. 